\title{
The Effects of Occupational Modality Therapy on the Independence Level of the Elderly
}

\author{
Miftah Apriani*, Ria Wulandari \\ Faculty of Midwifery and Nursing, Kader Bangsa University Palembang \\ Jl. Mayjend H.M. Rycudu No.88 Pangkal Ampera Palembang, Indonesia \\ *corresponding author, e-mail: mithayudhi62@gmail.com
}

Received: 25/01/2021; published: 21/08/2021

\begin{abstract}
Background: Independence in elderlies is the ability to carry out daily activities. The Activity of Daily Living (ADL) is a form of measuring a person's ability to perform ADL independently so that information on elderly morbidity can be analyzed. Occupational therapy is the art and science of supporting interactions in everyday life through work (occupation) that enables people to do work that promotes health and well-being and enables a just and inclusive society, encouraging everyone to optimize their potential in the workplace from everyday life. This study aims to identify the independence level of elderlies before and after occupational modality therapy. Methods: The method employed in this study was a quasi-experimental technique design using a pretest-posttest control group design. Results: The results of the study showed a p-value of 0.00 , indicating that occupational modality therapy affected the level of independence of the elderlies who were given treatment with a change of independence level from 13.50 to 16.95. Meanwhile, in the control group where the respondents were not given occupational modality therapy, there was no significant difference before and after the final observation. Conclusion: The elderlies who were given treatment became more independent in carrying out their daily activities compared to those who were not given treatment in the control group.
\end{abstract}

Keywords: Occupational Modality Therapy, Level of Independence, Elderly

This is an open access article under the CC-BY-SA license.

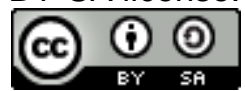

\section{Introduction}

The increasing number of elderlies will cause many comprehensive problems for the elderlies themselves, their families, and community groups [1-2]. Various kinds of challenges due to aging affect various aspects of life. The aging process is a natural thing that occurs physiologically and will be experienced by every human being; the conditions that elderlies have can cause various kinds of problems, both physically, psychologically, socially and economically [3-4].

Currently, the number of elderly people is estimated to be more than 629 million worldwide (one in ten people is over 60 years old), and by 2025, the number will reach 1.2 billion. According to the estimate from the Central Statistics Agency in 2005 in Indonesia, there are $18,283,107$ elderly people. This number will increase to \pm 33 million (12 percent of the total population) in 2020 with a life expectancy of approximately 70 years [5-7].

Occupational therapy is a therapy that is carried out in the form of psychotherapy to train the elderlies to do activities independently $[8,9]$. This therapy focuses on the functional abilities of the elderlies and ways to improve psychomotor skills in order to stimulate and facilitate them to do their activities [9-10]. The independence of an elderly is judged by their health condition. It is when they can carry out activities independently without depending on others [10-11].

The elderlies who receive occupational therapy will experience changes that are not experienced by those who are not given the therapy. In increasing the independence of the 
elderly to maintain their quality of life, modality therapy in the form of occupational therapy is utilized [12].

Based on data obtained from Panti Sosial in Ogan Ilir Regency, there were 80 elderly people, consisting of 35 elderly men and 45 elderly women at the institution. The result of interviews with health workers suggests that the level of independence of the elderly was still low. Activities that were usually done by the elderlies to increase their independence included making handicrafts, such as doormats, having recitals, and doing elderly gymnastics. However, not all the elderlies regularly participated in these activities. Based on this phenomenon, a study has been conducted to observe the effects of occupational modality therapy on the level of elderly independence and identify any changes before and after the therapy was carried out.

\section{Method}

This study is quasi-experimental using a T-Test design. In this design, there were two groups selected at random. The groups were given a pretest (preliminary observation) to determine the difference in initial conditions between the treatment and control groups before being given intervention or special treatment $(\mathrm{O})$ for the treatment group. After the intervention was given, a posttest (final observation) was carried out in both groups.

The data used were primary and secondary data. The secondary data was obtained from the medical records of the Elderly Social Institution and was analyzed through a checklist using the Barthels ADL index and a bibliography. The data processing went through several stages, namely data editing, data coding, data entry/ tabulation, and data cleaning. The sample in this study was took with a ratio of 1:1 for the treatment and control groups with 20 elderlies each for the treatment and control group. The analysis of the data was executed using the Wilcoxon test using SPSS version 22.

\section{Results and Discussion}

\subsection{Results}

3.1.1. Univariate Analysis

Based on Table 1, it can be seen that, in the treatment group, most participants were $65-70$ years old with as many as 10 people (50\%) and, in the control group, most participants were 60-64 years old with as many as 9 people (45\%). In terms of sex, in the treatment group, the majority of the participants were of female with 15 people $(75 \%)$. Similarly, most participants in the control group were also female with as many as 11 people (55\%). More details can be seen on Table 1.

Table 1. Characteristics of Respondents

\begin{tabular}{lcccc}
\hline \multirow{2}{*}{$\begin{array}{l}\text { Respondent } \\
\text { Characteristics }\end{array}$} & \multicolumn{2}{c}{ Treatment Group } & \multicolumn{2}{c}{ Control Group } \\
\cline { 2 - 5 } Age & 7 & & & \\
60-64 year & 10 & 35 & 9 & 45 \\
65-70 year & 3 & 15 & 4 & 20 \\
$71-75$ year & 15 & 75 & 7 & 35 \\
Sex & 5 & 5 & 11 & 55 \\
$\quad$ Woman & & & & 45 \\
$\quad$ Man & &
\end{tabular}

3.1.2. Bivariate Analysis

Table 2 shows that in the post-occupational therapy treatment group, the p-value was $<0.05$, meaning that there was a significant effect on the level of independence of the elderlies. Meanwhile, the control group obtained a $p$-value $>0.05$, indicating that there was no significant effect on the level of independence of the elderlies. More details can be seen on Table 2. 
Table 2. Bivariate Analysis Research

\begin{tabular}{ccccc}
\hline & \multicolumn{2}{c}{ Treatment Group } & \multicolumn{2}{c}{ Control Group } \\
\cline { 2 - 5 } & $\boldsymbol{P}$-value & Mean & P-value & Mean \\
\hline Pre-test & & 13.50 & & 13.50 \\
Post-Test & 0.0001 & 16.95 & 1.000 & 13.50 \\
\hline
\end{tabular}

\subsection{Discussion}

In this discussion, the level of independence of the elderlies who were given occupational modality therapy and those who did not is explained. Being old is a natural process, meaning that someone must go through three stages of life, namely being a child, an adult and an elderly [13,14]. Previous research found that elderly people who depend on Activity of Daily Living (ADL) fulfillment need help in carrying out their daily activities despite being assisted by health service team to lower their dependence level for those with diseases [15-16].

The independence of the elderly can be seen from the quality of life of the elderly themselves. The quality of life can be assessed by the ability to do ADL. The independence referred to in this study is the independence of the elderly in taking care of themselves, such as in eating, dressing up, defecating, and bathing [11,17-18]. The application of occupational therapy in the elderly is highly beneficial for elderlies with degenerative diseases since it aims to make the elderly feel happy to create a good well-being [19-20]. Occupational therapy for the elderlies is a form of treatment designed to help them lead a more productive and independent life. This form of therapy focuses on improving life skills with the aim of promoting a better quality of life. Occupational therapy is a form of therapy that directly activates the elderly's independence to do daily activities optimally [21-22].

Based on the results of research using the Wilcoxon test, it is found that occupational modality therapy had a significant effect on the level of independence of the elderlies $(p<0.05)$ in the treatment group with an average score of 16.95. On the other hand, in the control group where the treatment was not given, there was no significant difference between before and after the final observation.

After the intervention that lasted for approximately 2 weeks, changes in the level of independence of the elderly in the treatment group and the control group statistically showed a difference, meaning that occupational modality therapy had a significant effect on the level of independence of the elderly. The elderlies in the treatment group were more likely to be enthusiastic in carrying out their daily activities [23].

Based on the study, it was found that there was an increase in the mean value of life before and after occupational therapy (recreation), where the meaningful life span before occupational therapy (recreation) was 9.00 and increased to 14.60. It can be concluded that the meaning of life after work is very influential on the quality of life of the elderly, causing a sense of happiness in oneself $[13,24]$. According to the study, the elderlies are benefited from the occupational therapy with the creative activities that can help them in the process of reducing stress [25]. The study shows that occupational therapy can restore one's health in carrying out daily activities and help increasing the independence of elderlies [12,26].

The application of therapy is very influential for the elderlies, making it easier for them to carry out disease prevention activities [27-28]. A research describes the many problems that occur in the daily activities of the elderly. Elderlies who are highly stressed will not be able to do independent activities optimally, such as bathing, dressing up, moving their bodies, and others [29-30]. Past research found that elderlies with dementia experience impaired cognitive abilities so that they cannot live comfortably due to limited equipment and a lack of ability to meet their needs [31].

It can be concluded that, in the treatment group, there were 20 elderly people who experienced mild dependence before being given the therapy. After the therapy, there was a change in the level of independence where all 20 people who had a mild level of dependence became independent. It is because the respondents implemented the occupational modality therapy for approximately 2 weeks. On the other hand, in the control group, there were 20 elderlies who experienced mild dependence at the initial observation and did not experience any changes after the final observation. 


\section{Conclusion}

Based on the result, it can be concluded that occupational modality therapy in elderlies is highly important. Elderlies who were given treatment became more independent in carrying out their daily activities, compared to those who were not treated. This research is expected to optimize the role of the government and public awareness in improving the quality and quantity of social institutions to improve the welfare of the elderlies, especially regarding their level of independence.

\section{References}

1. Wulandari A, Saleh I, Silviana. Factors Related To Worm Infection (Soil Transmitted Helminth) And Learning Achievement Among Elementary Students At Work Area Of Puskesmas Punggur. openjurnal.unmuhpnk. 2017; doi: http://dx.doi.org/10.29406/jjum.v2i4.340

2. Whangmahaporn P. Thai Elder Abuse Problems and Prevention. SSRN Electron J. 2020;6(2):46-56. doi: https://so02.tci-thaijo.org/index.php/IJCLSI/article/view/242597

3. G. FG, S. CD, E. TL, B. DD, G. PG. Cognitive Functioning, Aging, and Work: A Review and Recommendations for Research and Practice. J Occup Health Psychol. 2017;22(3):314-336. doi: https://psycnet.apa.org/doi/10.1037/ocp0000086

4. Wurma S, Diehlb M, Kornadtc AE, J GW, Wahle H-W. How Do Views On Aging Affect Health Outcomes in Adulthood and Late Life? Explanations for An Established Connection. Dev Rev. 2017;46:27-43. doi: https://doi.org/10.1016/j.dr.2017.08.002

5. Wen C, Albert C, Von HC. Equality in Access to Urban Green Spaces: A Case Study in Hannover, Germany, with A Focus on the Elderly Population. Urban For Urban Green. 2020;55. doi: https://doi.org/10.1016/j.ufug.2020.126820

6. KS T. Key Search Term For The Systematic Review Of Fall Prevention Interventions For Community Dwelling Older Adults The American Journal Of Occupational Therapy. Suppl Table 2 Evid. 2018;72(4):1-22. doi: doi: 10.5014/ajot.2018.030494.

7. SM R, ME S, J D. Occupational Therapy in the Promotion of Health and Well-Being. Am J Occup Ther. 2020;74(3). doi: https://doi.org/10.5014/ajot.2020.743003

8. Bailliard AL, Dallman AR, Carroll A, Lee BD, Szendrey S. Doing Occupational Justice: A Central Dimension of Everyday Occupational Therapy Practice. Can J Occup Ther. 2020;22. doi: https://doi.org/10.1177\%2F0008417419898930

9. AG F, K A, A P. Effectiveness of Occupational Therapy with Frail Community Living Older Adults. Scand J Occup Ther. 2017;14(4):240-9. doi: 10.1080/11038120601182958.

10. de Souza IMB, Sakaguchi TF, Yuan SLK, Matsutani LA, Do Espírito-Santo A de S, Pereira $\mathrm{CA}$ de B, et al. Prevalence of Low Back Pain in the Elderly Population: A Systematic Review. Clinics. 2019;74. doi: 10.6061/clinics/2019/e789. eCollection 2019.

11. D R. Faktor-Faktor Yang Berhubungan Dengan Kemandirian Lansia Di Kecamatan Wara Timur Kota Palopo. Semin Nas LP2M UNM. 2017;2(1). doi: https://ojs.unm.ac.id/semnaslemlit/article/view/4048

12. Sunardi, S., \& Renidayati R. Peningkatan Kemandirian Lansia Melalui Okupasi Terapi Dan Group Psychotheraphy Di PSTW Sabai Nan Aluih Sicincin Padang Pariaman. J Sehat Mandiri. 2020;15(2):134-44. doi: https://doi.org/10.33761/jsm.v15i2.319

13. Andhini NF. Terapi Okupasi Terhadap Makna Hidup. J Chem Inf Model. 2017;53(9):1689=1699. doi: https://ejournal.unsrat.ac.id/index.php/jkp/article/view/8141

14. Zhang Q, Wang C. Natural and Human Factors Affect the Distribution of Soil Heavy Metal Pollution: a Review. Water, Air, Soil Pollut. 2020;350. doi: https://doi.org/10.1007/s11270020-04728-2

15. Zhu H, Samtani S, Brown R, Chen H. A Deep Learning Approach for Recognizing Activity of Daily Living (ADL) for Senior Care: Exploiting Interaction Dependency and Temporal Patterns. MIS Q [Internet]. 2021;45(2):859-96. DOI:10.25300/MISQ/2021/15574

16. Murtiyani N, Haryani R. Studi Korelasi Demensia Dengan Tingkat Ketergantungan Lansia Dalam Pemenuhan Activities Of Daily Living. J Keperawatan. 2016;9(2):41-6. doi: https://e-journal.Ippmdianhusada.ac.id/index.php/jk/article/view/54

17. Şahin DS, Özer MA, Zubaroğlu M. Perceived Social Support, Quality of Life and Satisfaction with life in Elderly People. Educ Gerontol. 2019;45(1). doi: https://doi.org/10.1080/03601277.2019.1585065

18. Alexiou KI, Roushias A, Evaritimidis S, Malizos KN. Quality of Life and Psychological 
Consequences in Elderly Patients After A Hip Fracture: A Review. Clin Interv Aging. 2018;13:143-50. doi: 10.2147/CIA.S150067

19. Toledano-Gonzales A, Lebajos-Manzanares T, Romero-Ayuso DM. Occupational Therapy, Self-Efficacy, Well-Being in Older Adults Living in Residential Care Facilities: A Randomized Clinical Trial. Front Psychol. 2018;07. doi: https://doi.org/10.3389/fpsyg.2018.01414

20. Christina J-W, Nyboe PM, Anne-Le M. The Influence of Occupation on Wellbeing, as Experienced by the Elderly: A Systematic Review. JBI Database Syst Rev Implement Reports. 2018;16(5):1174-89. doi: doi: 10.11124/JBISRIR-2016-003123

21. A S, H. IS, E. PS. Pengaruh Terapi Okupasi Terhadap Stres Pada Lansia. J Borneo Cendekia. 2019;1(1).

doi: http://journal.stikesborneocendekiamedika.ac.id/index.php/jbc/article/view/180

22. Febtriko A, Jama J, Irfan D, Dakhi O, Padang UN, Barat S. Effectiveness of Occupational Therapy Using Robot Manipulator for Elderly. Int J multi Sci. 2020;1(8):1-9. doi: https://multisciencejournal.com/index.php/ijm/article/view/103

23. R.W. W, C. W, P IC. Efektivitas Terapi Okupasi Dengan Olahraga Senam Low Impact Terhadap Skoring Stress Pada Lansia Di Balai Pelayanan Sosial Tresna Werdha Unit Abiyoso Pakem Sleman. Pros Semin Nas Multidisiplin IImu. 2019;1(1). doi: http://prosiding.respati.ac.id/index.php/PSN/article/view/43

24. Cho C, Bum CH. Physical Leisure Activity and Work For Quality of Life in the Elderly. $J$ Phys Educ Sport. 2019;19(2):1230-5. doi: https://doi.org/10.4047/jkap.2021.59.1.1

25. P. WN, E. TM. Pengaruh Penerapan Terapi Okupasi Terhadap Tingkat Stres Pada Lansia. J Keperawatan. 2017;6(1). doi: http://jurnal.stikeswilliambooth.ac.id/index.php/d3kep/article/view/59

26. Bolt M, Ikking T, Baaijen R, Saenger S. Occupational Therapy and Primary Care. Prim Heal Care Res Dev. 2019;20:1-6. doi: https://doi.org/10.1017/S1463423618000452

27. Hajian-Tilaki K, Heidari B, Hajian-Tilaki A. Are Gender Differences in Health-related Quality of Life Attributable to Sociodemographic Characteristics and Chronic Disease Conditions in Elderly People? Int J Prev Med. 2017;8(2). doi: 10.4103/ijpvm.IJPVM_197_16

28. A. Alshammari S, Alhassan AM, Abdulfattah FW. Falls Among Elderly and Its Relation with Their Health Problems and Surrounding Environmental Factors in Riyadh. J Family Community Med. 2018;25(1). doi: 10.4103/jfcm.JFCM_48_17

29. B P, D W. Hubungan Tingkat Stres Dengan Kemandirian Aktivitas Dalam Pemenuhan Kebutuhan Sehari-Hari Pada Lanjut Usia (Lansia). Nurs News (Meriden). 2019;4(2):11823. doi: https://doi.org/10.33366/nn.v4i1.1545

30. H I, L S. Pengaruh Terapi Okupasi Terhadap Stres Pada Lansia (Studi di Desa Balongbesuk Kecamatan Diwek Kabupaten Jombang). J Borneo Cendekia. 2018;2(1):136-43.

doi: http://journal.stikesborneocendekiamedika.ac.id/index.php/jbc/article/view/180

31. Mustayah, E W. Demensia Dengan Kemampuan Pemenuhan Kebutuhan ADL (Activity Of Daily Living) Pada Lansia Di Desa Kalirejo Wilayah Kerja Puskesmas Lawang - Malang Mustayah. 3rd Univ Res Colloq. 2016;170-81. doi: http://hdl.handle.net/11617/6748 